\title{
Implementation of Legal Norms \& Notaries Responsibility in the Making of a Deed of Grants
}

\author{
Nanda Herawati ${ }^{*}$ and Aryani Witasari ${ }^{* *}$ \\ ${ }^{*}$ ) Faculty of Law, Universitas Islam Sultan Agung (UNISSULA) Semarang, E-mail: \\ nandafumi22@gmail.com \\ $\left.{ }^{* *}\right)$ Faculty of Law, Universitas Islam Sultan Agung (UNISSULA) Semarang, E-mail: \\ aryani@unissula.ac.id
}

\begin{abstract}
The making of the grant deed must be carried out in the presence of an official authorized to make the deed, this is in accordance with the provisions contained in article 1682 of the Civil Code. In the case of land grants, the deed of grant is made before or by the Land Deed Making Official (PPAT). In making the grant deed, the Notary has an important role. The notary also keeps the deed of grant that has been made. The approach method used is normative juridical. The result of this research is that the authority of the Notary in making the Deed of Grant Agreement based on the Civil Code is in Article 1666 of the Civil Code which confirms that grants can be made and Articles 1671, 1672, 1687 of the Civil Code. The implementation of the land grant agreement made by a Notary on the basis of his authority must refer to the Civil Code in formulating the clauses in the Deed of Grant Agreement. Notaries are required to keep the contents of the deed and information obtained in the exercise of my position as stated in Article 4 paragraph (2) of the UUJN, it is also explained in Article 1909 paragraph (3) of the Civil Code that anyone who because of his position, work or position according to the law, must to keep something secret.
\end{abstract}

Keywords: Deed; Grant; Legal; Norms; Notary; Public.

\section{Introduction}

The State of Indonesia is a state of law and the law provides protection to human interests which regulates all relationships between individuals, individuals and groups and individuals with the government. Legal provisions are made to avoid disputes that arise in society, with the formation of legal norms, it is clear what 
actions may or may not be carried out in society, so as to create order in society. ${ }^{1}$ Protection of the community arises because of legal norms that require everyone to behave in such a way and if these norms are violated then those who violate will be subject to sanctions for punishment. ${ }^{2}$

Various legal regulations were created to regulate people's lives, one of which is agrarian law. The definition of agrarian in Subekti's opinion is all matters of land and everything in it and on it, as regulated in the Basic Agrarian Law. ${ }^{3}$ Along with the times, changes in land transformation are increasingly complex, accompanied by land problems that are present in people's lives. Land problems from an empirical perspective are closely related to daily events that arise from various policies and changes in the need for land, one of which is related to grants.

A grant is a gift from one person to another, usually when the giver or recipient is still alive. ${ }^{4}$ In the grant there is no counter-achievement element, the grantor surrenders his ownership of part or all of his assets to another party without any compensation from the recipient of the grant. In this regard, the legislators make rules that require the grantee to re-enter all the assets he has received into the inheritance of the grantor to be recalculated. ${ }^{5}$ Grants are a social function in society, so that land inheritance problems can be solved through grants.

In law, grants that have been given are non-refundable, but there are some exceptions that grants can be withdrawn and may be waived by the grantor. The government has regulated provisions regarding grants in article 1666 of the Civil Code (hereinafter referred to as the Civil Code), which reads:

"Grant is an agreement whereby the donor, during his lifetime, free of charge and irrevocably, surrenders an object for the purposes of the recipient of the grant who receives the delivery."

From the description above, it can be seen that the grant is a commendable act in which the grantor gives assets voluntarily without expecting anything in return, does not depend on and is not accompanied by any requirements. However, the granting of grants is often found in disputes with other heirs as well as against the grantor who does not agree on the grant, this ends up in the court table.

The making of the grant deed must be carried out in the presence of an official authorized to make the deed, this is in accordance with the provisions contained in article 1682 of the Civil Code. In the case of a land grant, the deed of grant is

\footnotetext{
${ }^{1}$ Mertokusumo, Sudikno. (2005). Mengenal Hukum sebagai Suatu Pengantar, Yogyakarta: Liberty, p. 1.

${ }^{2}$ Sutanto, Retnowulan. (2002). Hukum Acara Perdata dalam Teori dan Praktek, Bandung: Mandar Maju, p. 5.

${ }^{3}$ Harsono, Boedi. (2008). Hukum Agraria Indonesia, Jakarta: Djambatan, p. 14.

${ }^{4}$ Suparman, Eman. (1995). Intisari Hukum Waris Indonesia, Bandung: Mandar Maju, p.73.

${ }^{5}$ Amanat, Anisitus. (2001). Membagi Warisan Berdasarkan Pasal-Pasal Hukum Perdata BW, Jakarta: Raja Grafindo Persada, p. 70.
} 
made before or by the Land Deed Making Official (PPAT). The task of a PPAT is to carry out some land registration activities by making a deed as evidence of certain legal actions regarding land rights. The presence of the PPAT position is required by law which has the aim of assisting and serving the community who need authentic written evidence related to land regarding legal conditions, events or actions. ${ }^{6}$

Article 1 number 1 of Act No. 2 of 2014 concerning Regulations of Notary Positions (PJN), a Notary is a public official with the authority to make authentic deeds and other authorities as referred to in the Law from the formulation of Article 1 it is clear that the task of a Notary is to make a deed authentic and in addition to making a deed, there are other notary duties that are regulated outside the Notary Position Regulations. In accordance with the task of making authentic deeds or legalizing the signatures of the parties in private letters, or registering private letters, the making of a grant deed also follows the authority attached to the Notary in accordance with the legal service needs of the parties concerned. ${ }^{7} \mathrm{An}$ authentic deed made by or before a notary can be used as evidence in a legal dispute which is used as evidence to recall events that have occurred, so that it can be used for the sake of proof ${ }^{8}$.

Thus, it can be concluded that in making the deed of grant, the Notary has an important role. The notary also keeps the deed of grant that has been made. Article 943 of the Civil Code states that "Every notary who keeps the original documents, even in whatever form, must, after the beneficiary dies, notify all interested parties". As it is known that the application of legal norms in making a grant deed by a notary and the responsibility of a notary in making a grant deed, problems arise regarding the handling and settlement of a notary to avoid disputes that arise regarding the making of a grant deed ${ }^{9}$.

\section{Research Methods}

The approach method used in this research is the approachnormative juridical. This research method is a legal research method of literature where the method or method used in legal research is carried out by examining existing library

\footnotetext{
${ }^{6}$ Adjie, Habib. (2009). Hukum Notaris Indonesia, Bandung; Refika Aditama, p. 73.

${ }^{7}$ Kie, Tan Thong. (2011). Studi Notariat, Serba-serbi Praktek Notaris, Jakarta: Ichtiar Baru Van Hoeve, p. 579.

${ }^{8}$ A Chuasanga, Ong Argo Victoria. (2019). Legal Principles Under Criminal Law in Indonesia and Thailand, Jurnal Daulat Hukum, Vol 2, No 1 (2019) http://jurnal.unissula.ac.id/index.php/RH/article/view/4218 see also Deen, Thaufiq., Ong Argo Victoria \& Sumain. (2018). Public Notary Services In Malaysia. JURNAL AKTA: Vol. 5, No. 4, 10171026. Retrieved from http://jurnal.unissula.ac.id/index.php/akta/article/view/4135

${ }^{9}$ Ong Argo Victoria, Ade Riusma Ariyana, Devina Arifani. (2020). Code of Ethics and Position of Notary in Indonesia. Sultan Agung Notary Law Review 2 (4), 397-407, http://lppmunissula.com/jurnal.unissula.ac.id/index.php/SANLaR/article/view/13536 see also Yaya Kareng, Ong Argo Victoria, R. Juli Moertiyono. (2019). How Notary's Service in Thailand. Sultan Agung Notary Law Review, 1 (1), 46-56,http://jurnal.unissula.ac.id/index.php/SANLaR/article/view/4435
} 
materials. ${ }^{10}$ This research isAnalytical Descriptivenamely describing the applicable laws and regulations related to legal theories and their implementation practices. ${ }^{11}$ StudyAnalytical Descriptivethe intention is to obtain a comprehensive and systematic picture based on data that is correlated with one another about this research.

\section{Results and Discussion}

\subsection{Authority and Obligation of Notary in Making Grant Deed}

A grant is a gift event where this gift is given by someone who is referred to as a grantor to another person when the grantor is still alive and is also carried out when the grantor is still alive. Grant events are made based on a grant agreement. For family members who do not accept the gift, never criticize, because basically all property owned by a person is the full right that the owner of the property can freely give his wealth to anyone. ${ }^{12}$

Article 1666 of the Civil Code has regulated the definition of a grant, namely the process of giving something that belongs to the grantor to the donated. If there will be a grant process, then an agreement is made by the grantor and the grant is in a written agreement and is carried out in the presence of an authorized official. The land grant that will be made by the grantor to the grantee is still carried out with a written agreement made by and before a Notary and also PPAT.

In the provisions of the Law on Notary Positions Article 1 point 1 , hereinafter abbreviated as UUJN, states "A Notary is a Public Official who is authorized to make authentic deeds and has other authorities regulated in this law or other laws". The term for public officials is Openbare Amtbtenaren which means officials who have the duty to serve the community. A notary who acts as a public official has the task of making authentic deeds to serve the community. ${ }^{13}$

In the provisions contained in the UUJN, based on Article 15 paragraph (1) regarding the authority possessed by a Notary, namely "Notaries have the authority to make an authentic deed regarding all acts, agreements and stipulations required by law and/or desired by the law. concerned to be stated and stated in an authentic deed, and can guarantee the certainty of the date of

\footnotetext{
${ }^{10}$ Soekanto, Soerjono and Mamudji, Sri. (2009). Penelitian Hukum Normatif Suatu Tinjauan Singkat, Print-11, Jakarta, PT Raja Grafindo Persada, p. 13-14

${ }^{11}$ Suryabrata, Sumardi. (1993). Metodologi Penelitian, Jakarta:Rajawali, p.19

12 Hindrato, D. M. (2017). Pembatalan akta hibah oleh saudara kandung penerima hibah melalui penetapan pengadilan (studi penetapan Nomor: 581/Pdt. P/2015/PN. SBY) (Doctoral dissertation, UNS (Sebelas Maret University)), p. 80.

${ }^{13}$ Adolf, J. J., \& Handoko, W. Eksistensi Wewenang Notaris Dalam Pembuatan Akta Bidang Pertanahan. Notarius, Vol.3 (No.1), 181-192, p. 181-192.
} 
making the deed, keep the deed, provide grosse, copies and excerpts of the deed, as long as all of them are not delegated or assigned to other officials or other people stipulated by law. In this case, at the will of the law, the Deed of Grant Agreement can be made by a Notary who is also subject to the prevailing laws and regulations.

In addition to the above authorities, Article 15 paragraph (2) of the UUJN states that Notaries also have several powers, namely:

a. Validating signatures and ensuring the date of the letter;

b. Make bookkeeping;

c. Copy the original letter;

d. Match the copy;

e. Provide legal advice and legal consultation related to the deed made;

f. Making and honing deeds related to land objects;

g. Make and ratify the deed related to the implementation of the auction.

Based on Article 15 paragraph (2) in letter $f$ of the UUJN concerning the authority possessed by a Notary who makes a deed related to land, it can lead to several interpretations, namely Article 15 paragraph (2) in letter $f$ of the UUJN gives his authority to a Notary in making a deed related to However, it also indirectly regulates the limits of the authority possessed by a Notary to the authority of the PPAT, especially in the process of making the deed. ${ }^{14}$ In practice, the Notary's authority is only limited to making a deed, especially in land, the Notary's authority is limited to binding deeds and agreements regarding land because the proof of ownership of the land which is the object in the deed is still being managed at the authorized land office, and while waiting for the management process both parties have been bound by a binding deed or agreement made by a notary.

Proof of ownership of land whose management has been completed at the authorized land office is based on a binding deed or agreement made and ratified by a notary. In this case, especially the Deed of Grant Agreement on land, a Deed of Grant will be made by the Land Deed Making Officer (PPAT) and a transfer of rights regarding the land will be carried out based on the Deed of Grant, where the deed of grant is made by PPAT.

In carrying out his duties and authorities, a Notary must take an oath/promise before carrying out his position, a Notary must work honestly, thoroughly, impartially and of course be responsible for all legal actions taken.

\footnotetext{
${ }^{14}$ Sari, I. G. A. D., Wairocana, I. G. N., \& Resen, M. G. S. K. (2017). “Kewenangan Notaris dan Ppat dalam Proses Pemberian Hak Guna Bangunan Atas Tanah Hak Milik". Acta Comitas, Vol. 3, (No. 1), p.10.
} 
In relation to the responsibilities of a Notary, as an authorized public official, he is responsible for the legal actions taken, which in this case is the making of a deed of binding grants. The making of the deed of binding the grant, of course, cannot be separated from the obligations that must be carried out by a Notary, especially Article 16 paragraph (1) of the Amendment to the UUJN which states that "in carrying out his position a Notary is obliged to act honestly, thoroughly, independently, impartially and safeguard the interests of the parties involved in legal actions".

Based on the written provisions in UUJN Article 15 paragraph (1), a Notary has the right to make a deed where one of them is the Deed of Grant Agreement on land, the Notary's authority is only limited to making a deed to bind the grantor and grantee first, if the management of evidence land ownership rights have been completed, then the authority of PPAT to make a Deed of Grant in order to be able to transfer ownership rights to the land.

\subsection{Application of Legal Norms in Making the Deed of Grant}

According to GHS Lumban Tobing, $\mathrm{SH}$ in his book entitled notary position regulations that the main authority of a notary is to make an authentic deed of authenticity from a notary deed sourced from article 1 of the notary position regulation where the notary is made a "public official" (openbaar ambtenaar), so that by Thus, the deed made by a notary in his position acquires the nature of an authentic deed, as referred to in Article 1868 of the Civil Code. The second explanation regarding the authority of a notary in the book GHS Lumban Tobing, $\mathrm{SH}$, namely the authority of a notary in general, is first stated in Article 1 of the notary position regulation that a notary is authorized to make a deed regarding all acts, ${ }^{15}$

From the explanation of the article above, we can conclude that the notary has general authority while the authority of other officials is in making the deed if it is stated expressly while the notary is declared by law the only authorized one. As for the deeds whose making is also assigned to other officials or by law, the making of them is excluded, among others: ${ }^{16}$

a. Deed of acknowledgment of children out of wedlock (article 28 of the Civil Code);

b. Minutes of negligence of the mortgage keeper (article 1227 of the Civil Code);

\footnotetext{
${ }^{15}$ Tobing, G.H.S Lumban. (1992). Peraturan Jabatan Notaris, Jakarta: PT Gelora Aksara Pratama, p 49.

${ }^{16}$ Ibid. p. 38
} 
c. Minutes of how to offer cash and concentration payments (articles 1405 and 1406 of the Civil Code);

d. Protest deed of money orders and checks (articles 143 and 281 of the KUHD); and

e. Civil Registry Deed (article 4 of the Civil Code).

The making of the deed referred to in number 1 to number 4 , a notary is authorized to make it together with other officials (also authorized to make it), while what is referred to in number 5 a notary is not authorized to make it, but only by employees of the civil registry office. The law on the position of a notary is explained regarding the authority of a notary, namely a notary is a public official who is authorized to make authentic deeds and other authorities as intended in this law.

Article 15 paragraph 1 of the notary position law states that a notary has the authority to make an authentic deed regarding all acts, agreements and stipulations required by laws and/or required by the interested parties to be stated in an authentic deed, guaranteeing the certainty of the date of making the deed, keep the deed, provide grosse, copies and quotations of the deed, all of which is as long as the making of the deed is not assigned or excluded to other officials or other people stipulated by law.

The notary is obliged to keep the contents of the deed and information obtained in the exercise of my position as stated in Article 4 paragraph (2) of the UUJN, it is also explained in Article 1909 paragraph (3) of the Civil Code that anyone who because of his position, work or position according to the law, those who are required to keep something secret, but only regarding matters whose knowledge is entrusted to them for the sake of this, if the notary violates the law, sanctions will be imposed.

\section{Conclusion}

The authority of the Notary in making the Deed of Grant Agreement based on the Civil Code is in Article 1666 of the Civil Code which emphasizes that grants can be made and Articles 1671, 1672, 1687 of the Civil Code. The implementation of the land grant agreement made by a Notary on the basis of his authority must refer to the Civil Code in formulating the clauses in the Deed of Grant Agreement. The Notary's authority to make a Deed of Grant Agreement on land is based on UUJN Article 15 paragraph (1), the Notary has the authority to make and ratify a deed where one of them is the Deed of Grant Agreement on land. The notary is obliged to keep the contents of the deed and information obtained in the exercise of my position as stated in Article 4 paragraph (2) of the UUJN, it is also explained in Article 1909 paragraph (3) of the Civil Code that anyone who because of his position, work or position according to the law, those who are required to keep something secret, but only regarding matters whose 
knowledge is entrusted to them for the sake of this, if the notary violates the law, sanctions will be imposed.

\section{References}

Journals:

[1] A Chuasanga, Ong Argo Victoria. (2019). Legal Principles Under Criminal Law in Indonesia and Thailand, Jurnal Daulat Hukum, Vol 2, No 1 (2019) http://jurnal.unissula.ac.id/index.php/RH/article/view/4218

[2] Adolf, J. J., \& Handoko, W. Eksistensi Wewenang Notaris Dalam Pembuatan Akta Bidang Pertanahan. Notarius, Vol.3 (No.1), 181-192.

[3] Deen, Thaufiq., Ong Argo Victoria \& Sumain. (2018). Public Notary Services In Malaysia. JURNAL AKTA: Vol. 5, No. 4, 1017-1026. Retrieved from http://jurnal.unissula.ac.id/index.php/akta/article/view/4135

[4] Hindrato, D. M. (2017). Pembatalan akta hibah oleh saudara kandung penerima hibah melalui penetapan pengadilan (studi penetapan Nomor: 581/Pdt. P/2015/PN. SBY) (Doctoral dissertation, UNS (Sebelas Maret University)).

[5] Ong Argo Victoria, Ade Riusma Ariyana, Devina Arifani. (2020). Code of Ethics and Position of Notary in Indonesia. Sultan Agung Notary Law $\begin{array}{lllll}\text { Review } & 2 & (4), & \text { 397-407, } & \underline{\text { http://lppm- }}\end{array}$ unissula.com/jurnal.unissula.ac.id/index.php/SANLaR/article/view/13536

[6] Sari, I. G. A. D., Wairocana, I. G. N., \& Resen, M. G. S. K. (2017). "Kewenangan Notaris dan Ppat dalam Proses Pemberian Hak Guna Bangunan Atas Tanah Hak Milik". Acta Comitas, Vol. 3, (No. 1).

[7] Yaya Kareng, Ong Argo Victoria, R. Juli Moertiyono. (2019). How Notary's Service in Thailand. Sultan Agung Notary Law Review, 1 (1), 46-56, http://jurnal.unissula.ac.id/index.php/SANLaR/article/view/4435

Books:

[1] Adjie, Habib. (2009). Hukum Notaris Indonesia, Bandung; Refika Aditama.

[2] Amanat, Anisitus. (2001). Membagi Warisan Berdasarkan Pasal-Pasal Hukum Perdata BW, Jakarta: Raja Grafindo Persada.

[3] Harsono, Boedi. (2008). Hukum Agraria Indonesia, Jakarta: Djambatan.

[4] Kie, Tan Thong. (2011). Studi Notariat, Serba-serbi Praktek Notaris, Jakarta: Ichtiar Baru Van Hoeve.

[5] Mertokusumo, Sudikno. (2005). Mengenal Hukum sebagai Suatu Pengantar, Yogyakarta: Liberty.

[6] Soekanto, Soerjono and Mamudji, Sri. (2009). Penelitian Hukum Normatif Suatu Tinjauan Singkat, Print-11, Jakarta, PT Raja Grafindo Persada.

[7] Suparman, Eman. (1995). Intisari Hukum Waris Indonesia, Bandung: Mandar Maju. 
[8] Suryabrata, Sumardi. (1993). Metodologi Penelitian, Jakarta: Rajawali.

[9] Sutanto, Retnowulan. (2002). Hukum Acara Perdata dalam Teori dan Praktek, Bandung: Mandar Maju.

[10] Tobing, G.H.S Lumban. (1992). Peraturan Jabatan Notaris, Jakarta: PT Gelora Aksara Pratama.

\section{Regulation:}

[1] Act No. 2 of 2014 concerning Amendments to Act No. 30 of 2004 concerning the Position of a Notary.

[2] Act No. 5 of 1960 concerning Agrarian Principles

[3] Code of Civil law 